\title{
PENERAPAN METODE USER-CENTER DESIGN (UCD) UNTUK E-COMMERCE INDUSTRI KREATIF
}

\author{
Doni Abdul Fatah ${ }^{1)}$, Rifky Maulana Yusron ${ }^{2)}$, Irma Dila Febrianti ${ }^{3)}$ \\ ${ }^{1,3}$ Prodi Sistem Informasi, Fakultas Teknik,Universitas Trunojoyo \\ ${ }^{2}$ Prodi Teknik Mesin, Fakultas Teknik,Universitas Trunojoyo \\ Jl. Raya Telang, PO BOX 2 Kamal, Bangkalan \\ E-mail : ${ }^{1}$ doni.fatah@trunojoyo.ac.id, ${ }^{2}$ rifky.myusron@ @trunojoyo.ac.id, \\ 3irmadila556@gmail.com
}

\begin{abstract}
ABSTRAK
Banyak sistem e-commerce dibangun yang ada berfokus pada bisnis, dengan fitur beragam namun tanpa melibatkan pengguna, sehingga belum tentu akan sesuai dengan kebutuhan pengguna baik dari segi antar muka, usability, dan fitur yang ada, informasi yang disajikan, dan beberapa alur proses yang digunakan, karena faktor-faktor tersebut sehingga membuat user dapat juga merasakan kesulitan atau furtasi dalam menggunakan aplikasi tersebut, sehingga menjadi penyebab menurunnya produktifitas pengguna. Sehingga solusinya adalah dengan membuat aplikasi $e$ commerce yang mudah digunakan sesuai dengan kebutuhan pengguna dengan metode User-Center Design (UCD) diimplementasikan pada UKM Komoditas pangan lokal Madura diharapkan dapat memberikan dampak positif dalam mempermudah proses jual beli serta dapat meningkatkan persaingan bisnis untuk memasarkan berbagai macam produk atau jasa. Penerapan metode UCD menggunakan empat proses Specify the context of use, Specify User and Organizational Requirements, Produce Design Solutions dan Evaluate designs against user requirements. Untuk pengujiannya dilakukan menggunakan Functionality dengan metode black box, untuk usability menggunakan USE Queissionaire skala Likert 1 s.d 7 dengan 30 pertayaan, pengujian dilakukan dengan melibatkan pengguna sebanyak 10 orang terdiri 5 pelaku usaha dan 5 calon konsumen, hasil pengujian Functionality menunjukan hasil bagus karena sistem bekerja sesuai dengan fungsinya tanpa ada kendala, sedangkan pengujian usability USE Queissionaire pada front end mendapat nilai Usefulness 6.075, Ease of Use 6.236, Ease of Learning 6.30, dan Satisfaction 6.485, sedangkan pengujian pada back end untuk Usefulness 6.475, Ease of Use 6.563, Ease of Learning 6.60, dan Satisfaction 6.542, sehingga sistem secara umum baik karena masih berada pada nilai rata-rata 6 ke atas.
\end{abstract}

Kata kunci : E-commerce, Interface, USE Queissionaire, User-Center Design

\section{ABSTRACT}

Many existing E-commerce systems are built that focus on business, with various features but without involving the user, so it will not necessarily suit the needs of users both in terms of interface, usability, and existing features, information presented, and some of the process flows required. used, because these factors make the user can also feel the difficulty or frustration in using the application, thus causing a decrease in user productivity. So the solution is to create an e-commerce application that is easy to use according to user needs with the User-Center Design (UCD) method implemented in SMEs. Madura local food commodities are expected to have a positive impact in facilitating the buying and selling process and can increase business competition to market various products. kinds of products or services. The application of the UCD method uses four processes Specify the context of use, Specify User and Organizational Requirements, Produce Design Solutions and Evaluate designs against user requirements. The test is carried out using Functionality with the black box method, for usability using a USE Queissionaire Likert scale 1 to 7 with 30 questions, the test is carried out by involving 10 users consisting of 5 business actors and 5 potential customers, the results of the Functionality test show good results because the system works in accordance with its function without any problems, while the USE Queissionaire usability test on the front end scored Usefulness 6.075, Ease of Use 6.236, Ease of Learning 6.30, and Satisfaction 6.485, while testing on the back end for Usefulness 6.475, Ease of Use 6.563, Ease of Use Learning 6.60, and Satisfaction 6.542 , so that the system is generally good because it is still at an average value of 6 and above.

Keywords: E-commerce, Interface, USE Queissionaire, User-Center Design. 


\section{PENDAHULUAN}

Usaha kecil dan menengah (UKM) merupakan pilar penopang perekomonian kerakyatan yang kokoh dan terbukti dapat bertahan ditengah gejolak global serta menjadi tulang punggung penyerapan tenaga kerja cukup besar. Berdasarkan data statistik, sektor UMKM menyumbang 99,99\% dari seluruh usaha yang ada, menyerap 96,92\% tenaga kerja sektor swasta dan menyumbang $57,14 \%$ terhadap produk domestik bruto Indonesia [1]. Selain itu, UMKM adalah penyelamat bangsa Indonesia dari gejolak dan krisis global. Selama lima tahun terakhir, kontribusi sektor UMKM terhadap produk domestik bruto (PDB) meningkat dari $57,84 \%$ menjadi $60,34 \%$, dan penyerapan tenaga kerja di sektor ini juga meningkat dari 96,99\% menjadi 97,22\% [2]. Menurut International Council for Small Business (ICSB), 90\% perusahaan adalah UMKM, menyumbang rata-rata $6.070 \%$ dari total lapangan kerja dan 50\% dari PDB [3]. Hal itu diperkuat [4] dengan menunjukkan bahwa peningkatan kesejahteraan hidup masyarakat dan terciptanya peluang kerja baru dipicu oleh keberadaan UMKM. Dr. H. Soekarwo mengungkapkan bahwa memanfaatkan teknologi digital untuk usaha skala besar maupun kecil akan memperoleh banyak manfaat [5].

Pengembangan sektor tanaman pangan merupakan salah satu strategi kunci untuk mendorong pertumbuhan ekonomi ke depan, tidak hanya sebagai sumber devisa negara yang besar, tetapi juga sebagai mata pencaharian bagi sebagian besar penduduk Indonesia. Makanan pokok adalah makanan seharihari yang paling penting, tergantung pada potensi sumber daya dan kearifan lokal. Dalam menghitung produk domestik bruto (PDRB) subsektor tanaman pangan dan hortikultura, beras, jagung, kedelai, kacang tanah, sayuran, buah-buahan, tanaman pangan lainnya, dan hasil sampingnya (seperti bubur beras dan singkong), termasuk. Di Madura jagung merupakan salah satu tanaman pangan unggulan, bahwa Madura sesuai untuk pengembangan komoditas tanaman pangan khusunya jagung, sedikitnya ada mencapai 300.000 hektar lahan potensial untuk jagung, dimana produksi jagung di Madura per hektar mencapai 10 ton. Melihat tren ini, banyak UKM Madura tidak hanya menggunakan jagung, tetapi juga bahan makanan seperti tepung jagung, minyak jagung, nasi jagung, tepung jagung, dan makanan olahan lainnya seperti bungkil jagung, brendi jagung, bungkil jagung, dan keripik jagung, ada banyak hal yang bisa diolah dengan jagung, seperti jagung tart kelapa dan lainnya,namun tren tersebut belum dibarengi dengan pemanfaatan teknologi dalam dunia bisnis, sehingga UKM yang ada masih belum dapat memperluas jaringan mitra bisnis, dan pemasarannya.

Perkembangan teknologi informasi berkembang pesat, hal ini mempengaruhi hampir setiap bidang kehidupan, termasuk bisnis, pendidikan, dan layanan [6]. Salah satu wujud dari perkembangan TI adalah internet. Hal ini sejalan dengan data tren Hootsuite dari Indonesia's World Internet and Social Media 2020, dengan total populasi 272,1 juta, pengguna ponsel unik 338,2 juta, dan pengguna internet 100 juta.75,4 juta orang, media sosial aktif. Jumlah pengguna: 160 juta, melonjak di tahun sebelumnya [7].

E-commerce adalah jenis aplikasi teknologi dalam bisnis yang dapat menghubungkan penjual dan pembeli potensial melalui dunia maya internet. Pembeli masa depan akan mengetahui tentang harga perusahaan, merek, fitur produk dan produk lainnya, serta akan dapat membeli dan menjual kapan saja, di mana saja melalui internet. Pada tingkat nasional [8], ada empat kemungkinan $e$ commerce, yakni meningkatkan efisiensi pasar, meningkatkan efisiensi operasional, serta memperluas akses dan jaringan pasar. Tetapi permasalahan yang ada sekarang adalah banyaknya aplikasi $e$ commerce yang ada belum mampu memenuhi kebutuhan pengguna atau kurang sesuai kebutuhan pengguna baik dari aspek interface, usability, fasilitas yang diberikan, informasi terkait, dan proses yang diterapkan. Hal ini menyulitkan pengguna untuk 
menggunakan e-commerce. Menurut User Interface Engineering, Inc, penelitian telah menunjukkan bahwa $60 \%$ dari waktu terbuang, produktivitas berkurang, dan frustrasi meningkat karena informasi yang dibutuhkan tidak ditemukan. Untuk mempermudah penggunaan sistem, maka dibuatlah aplikasi e-commerce dengan menggunakan metode User Center Design (UCD). Konsep metode UCD menghadirkan pengguna sebagai pusat dari proses pengembangan sistem. Sasaran, konteks, dan lingkungan sistem semuanya didasarkan pada pengalaman pengguna. Dengan cara ini, e-commerce yang dirancang akan memenuhi kebutuhan pengguna baik dari segi antarmuka pengguna, kemudahan penggunaan, peralatan yang disediakan, informasi terkait, dan sistem pembelian barang melalui $e$-commerce.

Pada penelitian ini dilakukan pembuatan sistem e-commerce dengan menggunakan metode User Center Design (UCD) sering disebut sebagai Human Centered Design, ini adalah pendekatan pengembangan sistem interaktif yang berfokus secara khusus pada pembuatan sistem yang berguna [9], proses desain antarmuka yang berfokus pada tujuan kegunaan, karakteristik pengguna, lingkungan, tugas, dan alur kerja di dalam desainnya. UCD adalah proses berulang yang menempatkan pengguna di pusat proses pengembangan sistem dan membangun desain dan evaluasi dari langkah 1 hingga implementasi berkelanjutan. Saat menerapkan metode UCD [10], dengan fase atau proses dijalankan, diantaranya (1). Menentukan konteks penggunaan Memahami dan mendefinisikan konteks pengguna dengan menjelaskan kondisi dan kondisi di mana pengguna menggunakan sistem (2). Tentukan persyaratan pengguna dan organisasi dan identifikasi persyaratan pengguna dan organisasi (3). Produce Design Solutions membuat desain sebagai solusi untuk sistem yang dianalisis (4). Evaluasi desain berdasarkan kebutuhan pengguna pada pengujiannya dilakukan dengan menggunakan metode USE Queissionaire [11][12][13].

\section{METODE}

Dalam penelitian ini menggunakan metode penelitian yang ditunjukkan dalam Gambar 1 Diagram alir yang dilakukan adalah sebagai berikut:

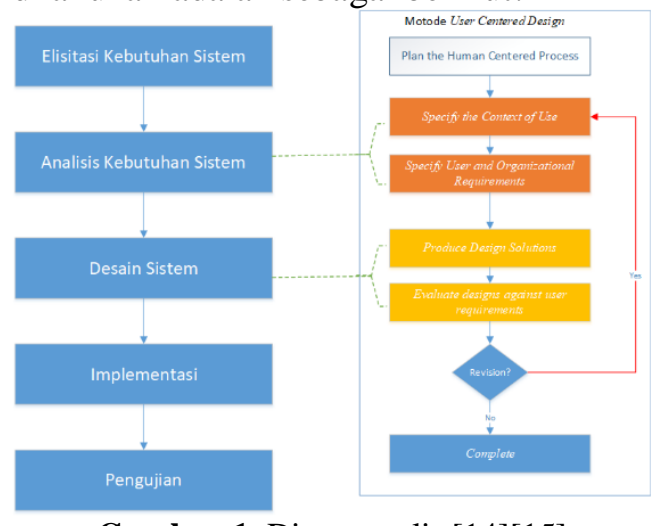

Gambar 1. Diagram alir [14][15]

Secara garis besar tahap yang dilakukan dapat diilustrasikan seperti pada gambar 1, diawali dengan proses elisitasi kebutuhan sistem [16], dimana dengan menyebar kuesioner untuk menentukan kebutuhan kepada para pelaku UKM yang menjadi target sasaran dalam penelitian. Hasil kuesioner kemudian dianalisa dan dirumuskan analisis kebutuhan sistem yang dibangun dengan memahami fitur-fitur dan cara kerja aplikasi akan dibangun.

Tahap analisa kebutuhan sistem merupakan tahapan yang dilakukan untuk mengerti kebutuhan pengguna terhadap sistem [17][18]. Pada analisa kebutuhan sistem ini menggunakan metode UCD ada 2 pendekatan yaitu (1) specity the context of use dengan cara memahami dan menentukan konteks pengguna dengan menjelaskan untuk apa sistem akan dibangun dan dalam kondisi seperti apa mereka akan menggunakan sistem tersebut, selanjutnya menggunakan (2) tahapan specify user and organizational requirement digunakan untuk mengidentifikasi apa saja kebutuhan dari calon pengguna atau user aplikasi dalam hal ini adalah para pelaku UKM dan calon pengguna aplikasi. Berdasarkan pada analisis kebutuhan sistem tersebut maka dilanjutkan dengan tahapan desain sistem, 
pada tahap desain ini dengan menggunakan metode UCD terdapat 2 pendekatan, pendekatan pertama produce design solutions digunakan untuk membangun desain antarmuka berdasarkan dari analisis kebutuhan dengan membuatkannya dalam bentuk wireframe untuk memberikan gambaran dan kerja dari sistem yang akan dibuat yang berguna untuk memahami bagaimana sistem nanti akan berjalan, pendekatan yang kedua evaluate designs against user requirements yang mana dari hasil perancangan tersebut kemudian diberikan atau ditujukan kepada calon pengguna untuk dilakukan evaluasi terhadap perancangan desain apakah sudah sesuai dengan kebutuhan pengguna atau belum, sehingga kalau memang desain tersebut belum sesuai dengan apa yang menjadi keiginan calon pengguna maka akan terjadi perbaikan berdasarkan hasil evaluasi dari calon pengguna tesebut dan akan diulangi lagi sesuai dengan tahapan sebelumnya, dan apabila sudah sesuai maka lanjut ke tahap selanjutnya implemtasi, pada kegiatan ini juga dilakukan perancangan flowchart, usecase diagram, pembuatan conceptual data model, physical data model dan model data relasional.

Tahap selanjutnya adalah implemetasi yang merupakan proses konversi rancangan sistem ke dalam bahasa pemrograman yang telah ditetapkan dalam hal ini menggunakan bahasa pemrograman HTML-PHP. Dalam proses pengembangan sistem ini, peneliti menggunakan bahasa pemrograman berbasis web sehingga tahapan ini akan menghasilkan suatu sistem berbasis web dan pengimplementasiannya dilakukan berdasar pada tahap-tahap sebelumnya sesuai kebutuhan calon pengguna.

Tahapan terakhir pengujian dengan cara memastikan dan mengukur kualitas sistem yang dibangun apakah sistem sudah berjalan sesuai dengan yang diinginkan dengan melakukan pengujian pada sistem yang telah dibangun dengan beberapa metode yaitu pengujian Functionality dengan menggunakan metode black box, pengujian usability dengan menggunakan pengisian USE Queissionaire dengan menggunakan 3 tiga parameter : kegunaan, kepuasan, kemudahan penggunaan, yang diberikan kepada pengguna untuk menyelesaikan skenario tugas dan 1-7 skala likert dalam 30 pertanyaan dengan menggunakan perangkat pengguna yang berbeda [19].

\section{HASIL DAN PEMBAHASAN}

a. Rancangan Sistem

Pada tahapan ini dibuatkan rancang bangun implementasi yang mencakup input, proses, dan output dari sistem yang diusulkan yang ditampilkan dalam bentuk wireframe, flowchart dan usecase diagram, dan model data relasional.

Sesuai dengan metode yang dijelaskan sebelumnya telah dilakukan wawancara kepada para pelaku usaha dan calon pengguna aplikasi untuk mengetahui kebutuhan apa saja yang dibutuhkan pengguna. Setelah diketahui kebutuhan apa saja yang dibutuhkan pengguna yaitu dengan melakukan spesifikasi kebutuhan fungsional dari masing-masing aktor, yang ditujukan seperti pada gambar 2 usecase diagram, untuk sistem yang dibangun menggunakan dua antar muka front-end antar muka untuk sisi penggunan dan back-end antar muka untuk pengelola data.

Saat membuat diagram use case, digunakan untuk mewakili hubungan antara aktor dan sistem, ini dapat mewakili interaksi antara satu atau lebih aktor dan sistem yang dibuat.

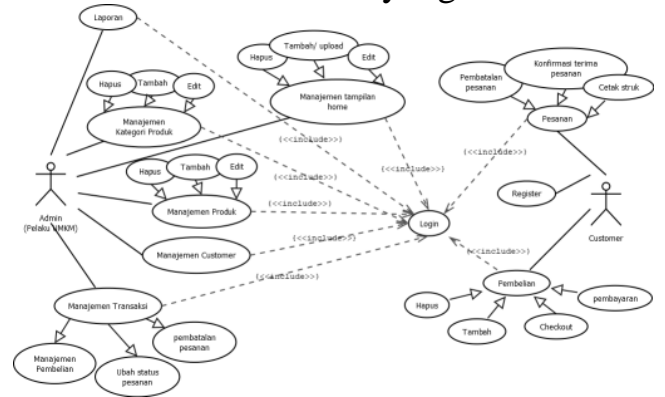

Gambar 2. Usecase Diagram Sistem ecommerce

Pada gambar 2, Use case sistem $e$ commerce terdiri dari 2 aktor yaitu admin 
dan customer. Admin dapat melakukan proses login, manajemen kategori dan produk, manajemen tampilan, manajemen pelanggan, manajemen transaksi dan mencetak laporan penjualan. Sedangkan kustomer dapat melakukan login, register, dan pembelian.

Sedangkan untuk penggunaan flowchart digunakan representasi dari alur sistem yang akan dibangun.

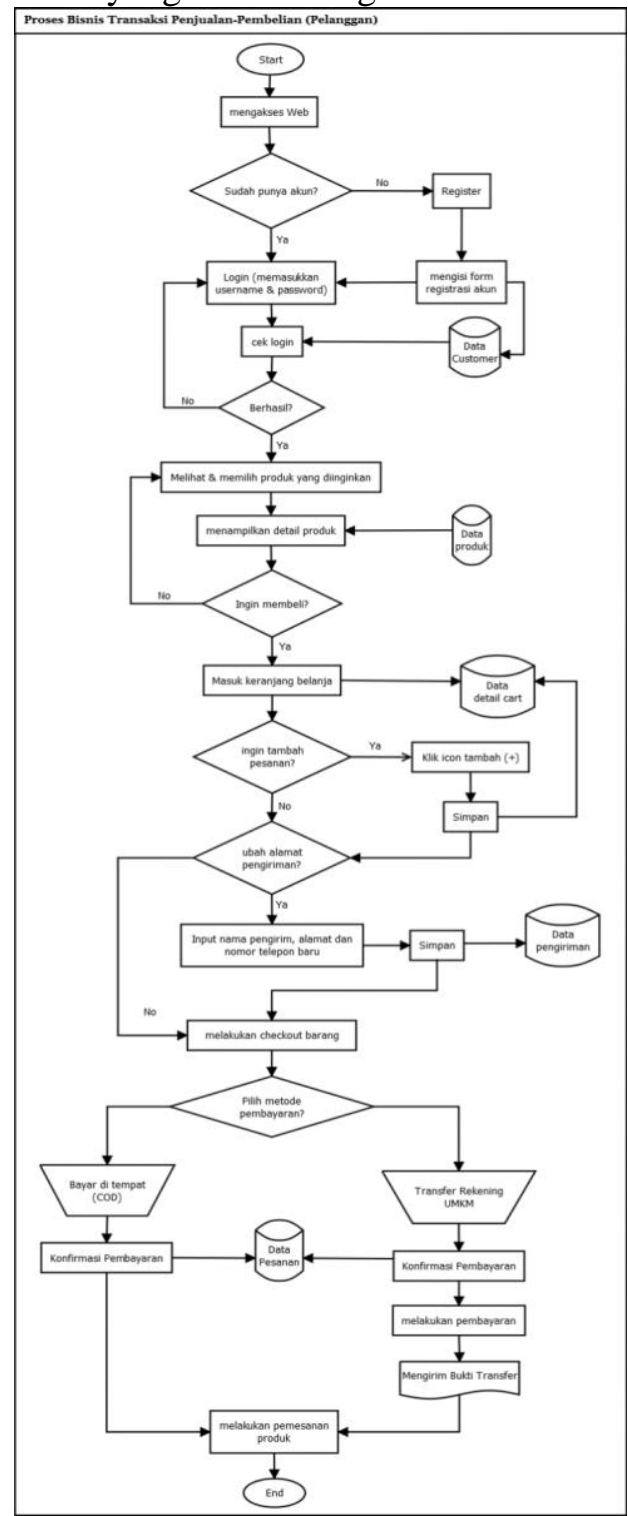

Gambar 3. Flowchart transaksi penjualanpembelian

Pada gambar 3, alur sistem diawali dengan user mengakses sistem. Sebelum melakukan transaksi pembelian, user diminta untuk login (jika sudah memiliki akun) dan daftar (jika belum memiliki akun). User login dengan menggunakan username dan password. Apabila user ingin membeli produk maka user harus memasukkannya ke keranjang. Di dalam keranjang user dapat melakukan perubahan jumlah produk dan alamat pengiriman. User akan melakukan checkout produk jika sudah yakin ingin membelinya. Setelah proses checkout maka user diminta untuk melakukan pembayaran dengan memilih metode pembayaran yaitu COD dan transfer rekening. Jika user telah melakukan konfirmasi pembayaran maka membuat pesanan produk yang telah dipilih.

Untuk model data relasional yang digunakan untuk menggambarkan sebuah berkas data, akan tetapi dalam basis data digunakan untuk memperjelas struktur dari jenis data yang tersimpan di dalamnya disebut sebagai skema basis data.

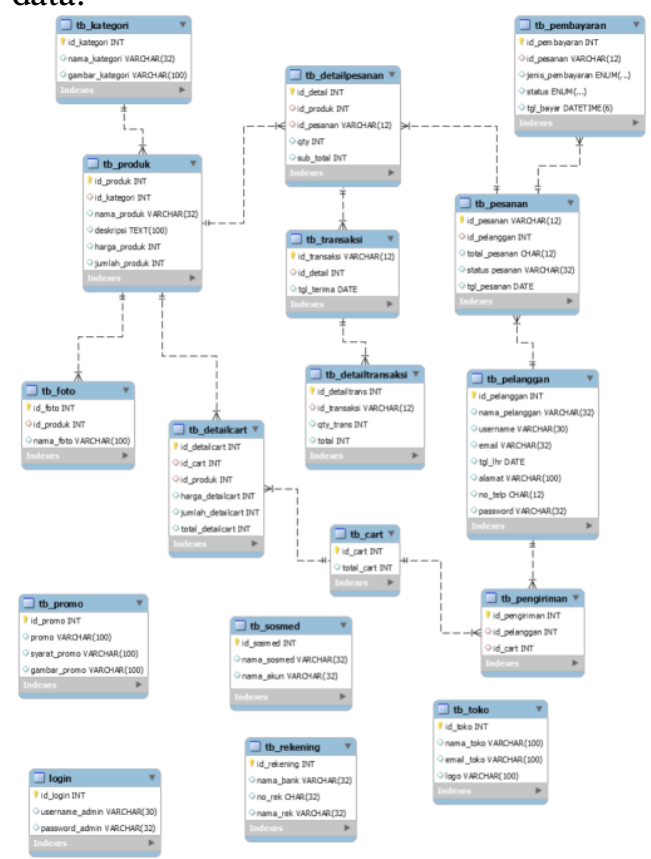

Gambar 4. Model database Relasional

Pada gambar 4, menjelaskan model relasi dari database yang dibangun pada sistem e-commerce.

Sedangkan untuk tampilan dari wireframe sistem yang dibangun adalah sebegai berikut. 


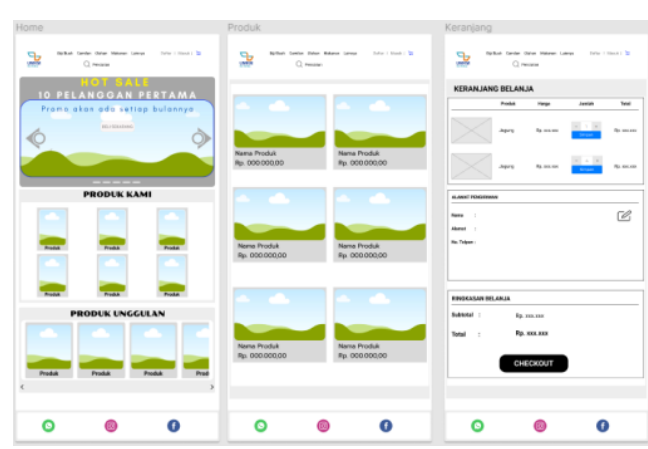

Gambar 5. Wireframe antarmuka Front-end

Pada gambar 5, adalah tampilan antarmuka pengguna aplikasi yang didalamnya terdapat beberapa menu tampilan mulai dari menu home, menu produk dan menu pembayaran atau keranjang, yang di dalamnya terdapat menu-menu sesuai dengan kegunaannya.

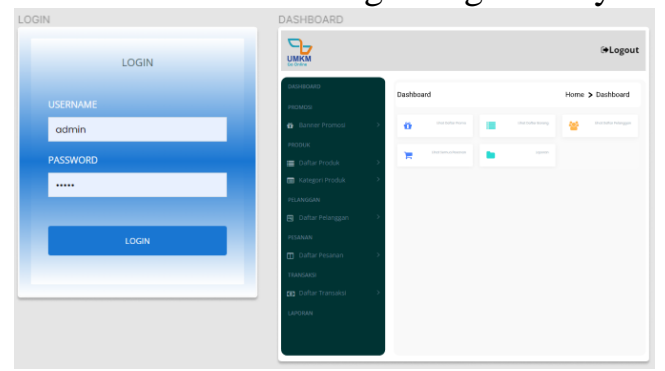

Gambar 6. Wireframe antarmuka back-end

Pada gambar 6, adalah wireframe antarmuka untuk admin atau pengelola aplikasi di dalamnya terdapat beberapa feature yang dapat digunakan untuk melakukan pengelolaan produk dan pesanan sesuai dengan feature yang dipilih.

Tampilan sistem e-commerce yang dibangun.

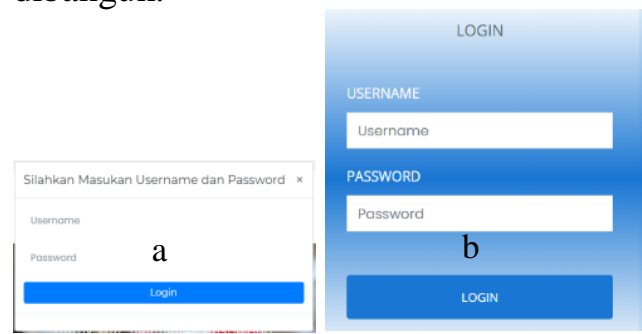

Gambar 7. Login sistem e-commerce (a) untuk pengguna, (b) untuk pengelola

Pada gambar 7 adalah Halaman login untuk (a) pengguna, (b) untuk pengelola di dalamnya terdiri dari 2 field yaitu username dan password. Jadi user harus login menggunakan username yang telah terdaftar

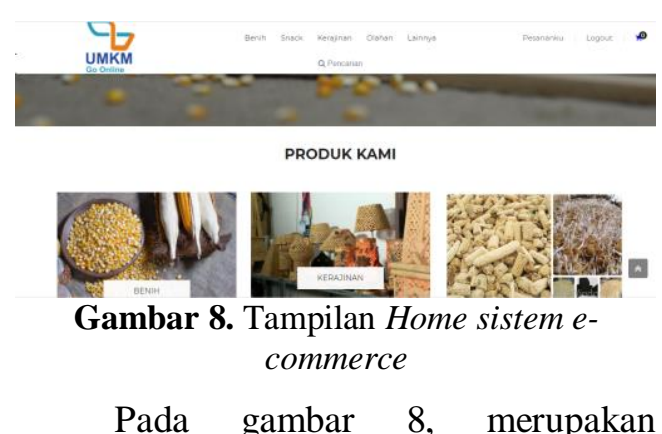
tampilan awal sistem yang dibangun, dimana terdapat beberapa menu produk yang ditawarkan.

\section{b. Pengujian sistem}

Pengujian pada penelitian ini dilakukan untuk memeriksa apakah suatu perangkat lunak yang dibangun sudah dapat berjalan sesuai dengan kebutuhan user (user requirement). Untuk pengujian pertama yaitu menguji functionality dengan menggunakan metode black box. Pada pengujian fungsionalitas menggunakan beberapa aktifitas diantaranya aktivitas login, register, pembelian, manajemen produk dan kategori, manajemen pesanan, halaman home, ditujukan pada tabel 1 di bawah.

Tabel 1. Pengujian aktifitas login dengan

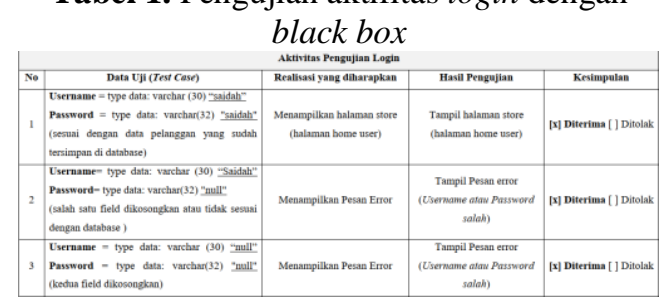

Pada tabel 1 dapat dijelaskan bahwa pada pengujian ini tidak ditemukan masalah sama sekali atau fungsi login dapat berjalan dengan baik, begitu juga untuk pengujian yang lainnya juga menunjukan hasil yang dapat diterima atau berjalan dengan fungsi semestinya.

Pengujian selanjutnya yaitu pengujian usability dengan menggunakan USE Queissionaire menggunakan 30 pertanyaan yang dibagi menjadi 4 kategori usefulness (kegunaan), ease of use (kemudahan penggunaan), ease of learning (mudah belajar), dan satisfaction (kepuasan). Untuk pertanyaan kuesioner USE dapat dilihat pada tabel 2 . 
Tabel 2. Pertanyaan Kuisioner USE

\begin{tabular}{|l|l|}
\hline No & Pertanyaan \\
\hline \multicolumn{1}{|l|}{ USEFULNESS } \\
\hline 1 & $\begin{array}{l}\text { Sistem } \text { E-Commerce UKM Ini membantu } \\
\text { saya menjadi lebih efektif. }\end{array}$ \\
\hline 2 & $\begin{array}{l}\text { Sistem } \text { E-Commerce UKM Ini membantu } \\
\text { saya menjadi lebih produktif. }\end{array}$ \\
\hline 3 & Dst... \\
\hline 8 & $\begin{array}{l}\text { Sistem } \text { E-Commerce UKM Ia melakukan } \\
\text { semua yang saya harapkan. }\end{array}$ \\
\hline EASE OF USE \\
\hline 9 & $\begin{array}{l}\text { Sistem } \text { E-Commerce UKM Mudah } \\
\text { digunakan. }\end{array}$ \\
\hline 10 & Dst... \\
\hline 19 & $\begin{array}{l}\text { Saya dapat menggunakan Sistem } \text { E- } \\
\text { Commerce UKM dengan sukses setiap } \\
\text { saat. }\end{array}$ \\
\hline EASE OF LEARNING \\
\hline 20 & $\begin{array}{l}\text { Saya belajar menggunakan Sistem } \text { E- } \\
\text { Commerce UKM dengan cepat. }\end{array}$ \\
\hline 21 & dst \\
\hline 23 & $\begin{array}{l}\text { Saya dengan cepat menjadi terampil } \\
\text { dengan Sistem E-Commerce UKM itu. }\end{array}$ \\
\hline SATISFACTION \\
\hline 24 & $\begin{array}{l}\text { Saya puas dengan Sistem } \text {-Commerce } \\
\text { UKM itu. }\end{array}$ \\
\hline 25 & Dst... \\
\hline 30 & $\begin{array}{l}\text { Sistem } \text { E-Commerce UKM Sangat } \\
\text { menyenangkan untuk digunakan. }\end{array}$ \\
\hline
\end{tabular}

Selanjutnya dari setiap kuesioner tersebut disebarkan kepada responden yang dibagi ke dalam 2 bagian kuesioner untuk front End dan kuesioner untuk back end, pada setiap kuesioner tersebut dibagi kedalam 4 kategori yaitu usefulness, ease of use, ease of learning, dan satisfaction, dari masing-masing kategori tersebut kemudian dihitung nilai skor rata-rata untuk setiap pertanyaan sehingga didapatkan hasil.

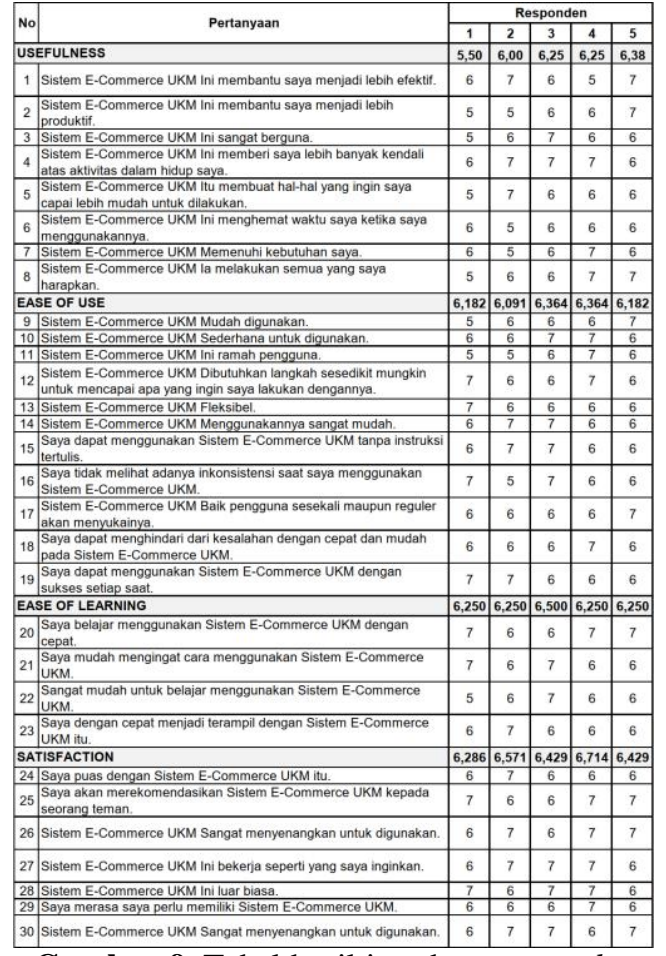

Gambar 9. Tabel hasil jawaban responden terhadap pertanyaan kuisioner USE pada bagian Front end aplikasi.

Pada gambar 9 di atas menjelaskan hasil dari pertanyaan yang telah diberikan kepada responden pada bagian front end aplikasi E-Commerce, dimana terdapat beberapa point yang ditanyakan usefulness, ease of use, ease of learning dan satisfaction, untuk rekap hasilnya dapat dilihat pada gambar grafik di bawah.

Untuk pengujian pada bagian front end aplikasi didapatkan hasil yang dapat dilihat pada gambar di bawah :

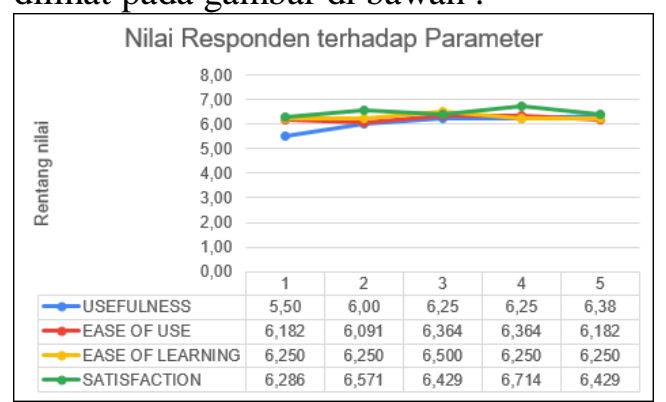

Gambar 10. Nilai Hasil responden terhadap parameter pertanyaan pada bagian front end aplikasi

Pada gambar 10 di dapatkan hasil bahwa rata-rata nilai untuk setiap elemen pertanyaan secara keseluruhan yang mana menunjukan hasil yang baik karena 
berada pada range nilai 5,50 untuk yang terendah dan 6,71 untuk nilai yang tertinggi dari 4 parameter usefulness, ease of use, ease of learning, dan satisfaction.

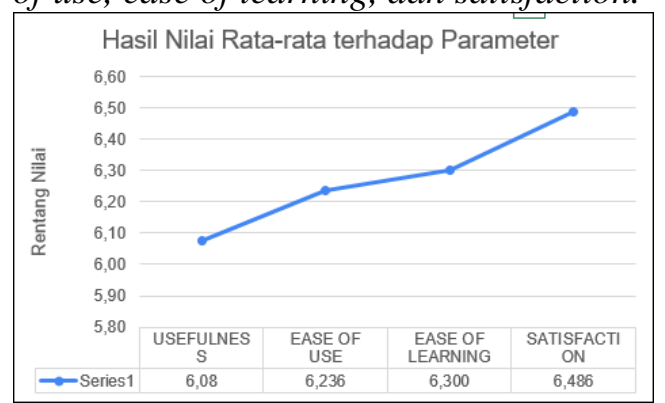

Gambar 11. Hasil nilai rata-rata terhadap 4 parameter pada bagian front end aplikasi

Pada gambar 11 dapat di lihat bahwa dari 4 paremeter yang ada menunjukan hasil yang baik karena berada pada range 6,08 untuk nilai terendah dan 6,48 untuk nilai tertinggi.

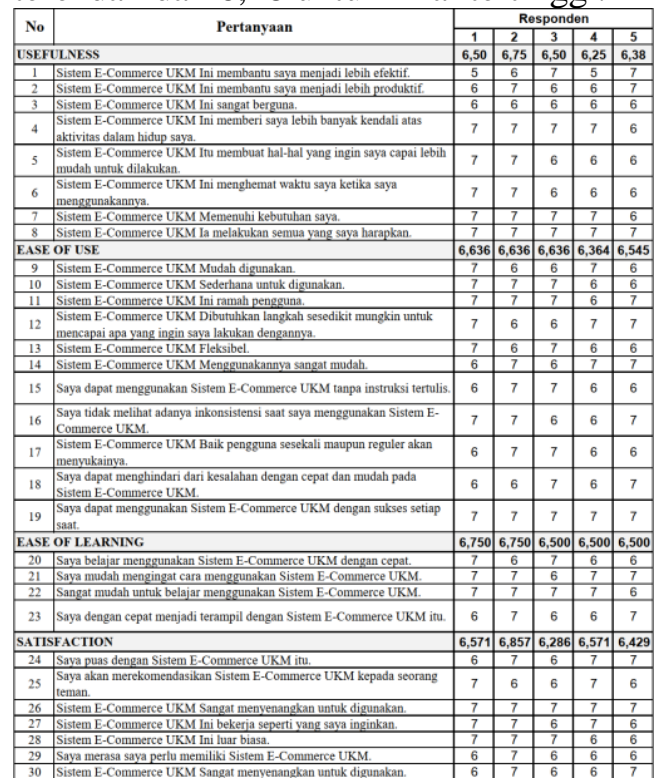

Gambar 12. Tabel hasil jawaban responden terhadap pertanyaan kuisioner USE pada bagian back end aplikasi.

Pada gambar 12 di atas menjelaskan hasil dari pertanyaan yang telah diberikan kepada responden pada bagian back end aplikasi e-commerce, dimana terdapat beberapa point yang ditanyakan usefulness, ease of use, ease of learning dan satisfaction, untuk rekap hasilnya dapat dilihat pada gambar grafik di bawah.

Sedangkan untuk pengujian pada bagian back end aplikasi didapatkan hasil,

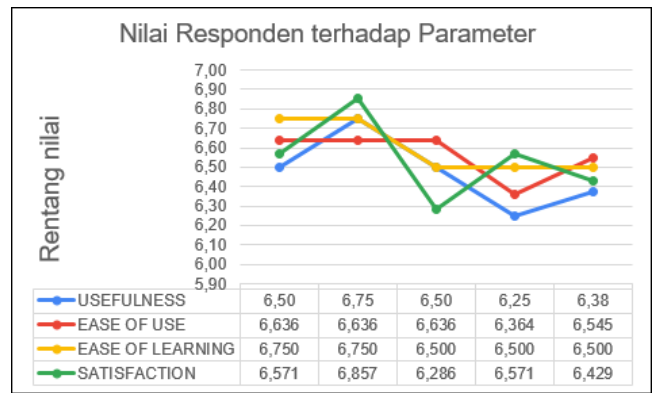

Gambar 13. Nilai Hasil responden terhadap parameter pertanyaan pada bagian back end aplikasi

Pada gambar 13 di dapatkan hasil bahwa nilai rata-rata pada setiap elemen pertanyaan secara keseluruhan yang mana menunjukan hasil yang lebih baik dari bagian front end karena berada pada range nilai 6,25 untuk yang terendah dan 6,85 untuk nilai yang tertinggi dari 4 parameter usefulness, ease of use, ease of learning, dan satisfaction.

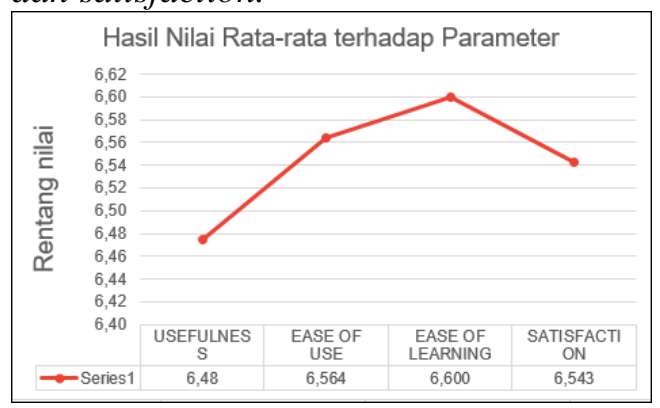

Gambar 14. Hasil nilai rata-rata terhadap 4 parameter pada bagian back end aplikasi

Pada gambar 14 menunjukan bahwa nilai yang didapat mendapatkan nilai yang lebih bagus dari pada bagian front end terlihat dari hasil yang didapatkan terhadap 4 parameter usefulness, ease of use, ease of learning, dan Satisfaction, dimana untuk nilai terendah berada pada range 6,48 dan nilai tertinggi berada pada range 6,60 .

Sedangkan perbandingan pengujian usability yang dilakukan terhadap aplikasi pada bagian front end dan back end dapat di lihat pada gambar 15 . 


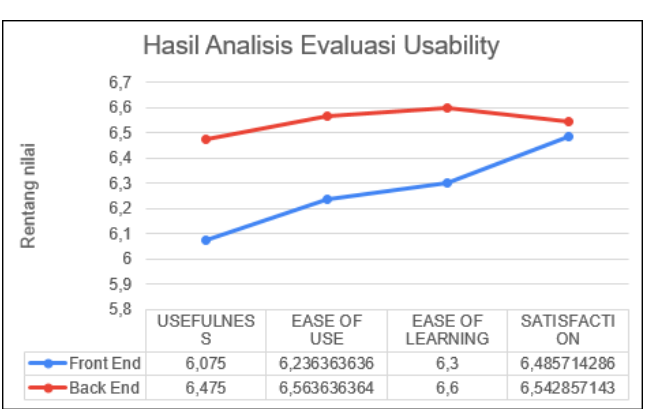

Gambar 15. Perbandingan nilai hasil analisis evaluasi usability terhadap 4 parameter pada bagian front end dan back end.

Pada gambar 15 menunjukan hasil bahwa pengujian usability menggunakan USE Queissionaire dengan menggunakan 30 pertanyaan dan 4 parameter pada sistem e-commerce UKM pada bagian back end maupun front end, di dapatkan hasil pada bagian front end usefulness 6.075, ease of use 6.236, ease of learning 6.30 , dan satisfaction 6.485 , sedangkan pengujian pada bagian back end di dapatkan hasil usefulness 6.475 , ease of use 6.563, ease of learning 6.60, dan satisfaction 6.542, sehingga dapat disimpulkan bahwa sistem e-commerce UKM secara umum baik karena masih berada pada nilai rata-rata 6 ke atas dan sudah dapat diterima dengan baik oleh pengguna, dianggap bermanfaat, dapat membantu pekerjaan serta tinggkat kepuasan user juga baik.

\section{SIMPULAN}

Berdasarkan pada hasil penelitian yang telah dilakukan sesuai dengan tahapan-tahapan yang diusulkan sehingga didapatkan hasil bahwa untuk nilai pada pengujian Usability menggunakan USE Queissionaire menunjukan hasil yang bagus sehingga sistem dapat diterima oleh pengguna terlihat dari hasil pengujian pada bagian front end usefulness 6.075, ease of use 6.236, ease of learning 6.30, dan satisfaction 6.485, sedangkan pengujian pada bagian back end di dapatkan hasil usefulness 6.475 , ease of use 6.563, ease of learning 6.60, dan satisfaction 6.542. serta telah dilakukan pengujian functionality dengan menggunakan metode black box pada beberapa aktifitas diantaranya aktivitas login, register, pembelian, manajemen produk dan kategori, manajemen pesanan, halaman home menunjukan hasil yang bagus karena sistem e-commerce UKM bekerja sesuai dengan fungsinya tanpa ada kendala di dalamnya.

\section{SARAN}

Kedepannya sistem ini masih dapat dikembangkan lagi terutama sesuai dengan perkembangan teknologi sehingga dipenelitian selanjutkan dapat dipadukan dengan menggunakan kecerdasan buatan sebagai rekomendasi penguna dan pengujian usabilitynya dapat dibandingkan dengan menggunakan metode yang lainnya misalnya system usablity scale (SUS), single ease question (SEQ) dan yang lainnya.

\section{DAFTAR PUSTAKA}

[1] Kementrian KUKM, "Perkembangan Data Usaha Mikro , Kecil , Menengah Dan Usaha Besar,' Www.Depkop.Go.Id, vol. 2000, no. 1, p. 1, 2018, [Online]. Available: https://www.kemenkopukm.go.id/up loads/laporan/1617162002_SANDI NGAN_DATA_UMKM_20182019.pdf.

[2] A. Prasetyo, "UMKM Sumber Ekonomi Baru Indonesia," www.mediaindonesia.com, 2017. https://mediaindonesia.com/ekonomi /118207/umkm-sumber-ekonomibaru-indonesia (accessed May 10, 2021).

[3] www.lalamove.com, "Mengapa UMKM Penting bagi Perekonomian? Ini 4 Alasannya," www.lalamove.com, 2020. https://www.lalamove.com/indonesi a/jakarta/id/blog/4-alasan-bisnisumkm-penting (accessed May 10, 2021).

[4] Okfalisa, W. Anggraini, and Identiti, Kesiapan Usaha Mikro Kecil dan Menengah (UMKM) di Indonesia Menuju Bisnis Digital, 1st ed. Pekanbaru: UR Press, 2020.

[5] kumparan.com, "Tingkatkan daya saing UMKM melalui teknologi digital," kumparan.com, 2018. 
https://kumparan.com/kabarbisnis/ti ngkatkan-daya-saing-umkmmelalui-teknologi-digital1540336352944617747/full (accessed May 10, 2021).

[6] A. Sani, N. Wiliani, A. Budiyantara, and N. Nawaningtyas, "Pengembangan Model Adopsi Teknologi Informasi Terhadap Model Penerimaan Teknologi Diantara Umkm," JITK (Jurnal Ilmu Pengetah. dan Teknol. Komputer), vol. 5, no. 2, pp. 151-158, 2020, doi: $10.33480 /$ jitk.v5i2.1055.

[7] We Are Social \& Hootsuite, "Indonesia Digital report 2020," Glob. Digit. Insights, p. 43, 2020.

[8] R. Ardianti, "Perkembangan Adopsi e-commerce dan Implikasinya bagi Manajemen Organisasi Bisnis," Akunt. dan Keuang. Pulit Petra, no. 2007, 2016.

[9] www.interaction-design.org, "User Centered Design," www.interactiondesign.org, 2021. https://www.interactiondesign.org/literature/topics/usercentered-design (accessed May 10, 2021).

[10] N. Babich, "User Centered Design Principles \& Methods," xd.adobe.com, 2019 . https://xd.adobe.com/ideas/principle s/human-computer-interaction/usercentered-design/ (accessed May 10, 2021).

[11] K. R. Hadi, H. M. Az-zahra, and L. Fanani, "Analisis Dan Perbaikan Usability Aplikasi Mobile KAI Access Dengan Metode Usability Testing Dan Use Questionnaire," $J$. Pengemb. Teknol. Inf. dan Ilmu Komput., vol. 2, no. 9, p. 2743, 2018.

[12] D. R. Rahadi, "Pengukuran Usability Sistem Menggunakan Use Questionnaire Pada Aplikasi Android," vol. 6, no. 1, pp. 661-671, 2014

[13] K. Aelani and Falahah, "Pengukuran Usability Sistem Menggunakan Use Questionnaire," Semin. Nas. Apl. Teknol. Inf. 2012 (SNATI 2012), vol. 2012, no. Snati, pp. 15-16, 2012.
[14] A. Krisnoanto, A. H. Brata, and M. T. Ananta, "Penerapan Metode User Centered Design Pada Aplikasi ELearning Berbasis Android ( Studi Kasus: SMAN 3 Sidoarjo )," $J$. Pengemb. Teknol. Inf. dan Ilmu Komput. Univ. Brawijaya, vol. 2, no. 12, pp. 6495-6501, 2018.

[15] R. I. Gunawan, Muh Indra Rokhmawati and N. H. Wardani, "Evaluasi dan Perbaikan Antarmuka Pengguna Menggunakan Pendekatan User Centered Design ( UCD ) dan Card Sorting," vol. 1, no. 1, 2017.

[16] A. Silva, P. Pinheiro, A. Albuquerque, and J. Barroso, "A process for creating the elicitation guide of non-functional requirements," Adv. Intell. Syst. Comput., vol. 465, pp. 293-302, 2016, doi: 10.1007/978-3-31933622-0_27.

[17] Z. Rustamin and A. P. Dewi, "Sistem Pengarsipan Surat Masuk Dan Surat Keluar Pada Kantor Sekretariat Dprd Provinsi Sulawesi Tenggara Menggunakan Borland Delphi 7," Simtek J. Sist. Inf. dan Tek. Komput., vol. 1, no. 2, pp. 165-172, 2016, doi: 10.51876/simtek.v1i2.21.

[18] D. A. Fatah, "Evaluasi Usability dan Perbaikan Desain Aplikasi Mobile Menggunakan Usability Testing dengan Pendekatan Human-Centered Design (HCD)," Rekayasa, vol. 13, no. 2, pp. 130-143, 2020, doi: 10.21107/rekayasa.v13i2.6584.

[19] M. Younas, D. N. A. Jawawi, I. Ghani, and R. Kazmi, "NonFunctional Requirements Elicitation Guideline for Agile Methods," $J$. Telecommun. Electron. Comput. Eng., vol. 9, no. 3-4 Special Issue, pp. 137-142, 2017. 